\title{
Anticancer activity study of ethanol extract of Mahkota dewa fruit pulp (Phaleria macrocarpa (Scheff.) Boerl.) in C3H mouse mammary tumor induced by transplantation
}

\author{
Erni Rahmawati, Hedi R. Dewoto*, Puspita Eka Wuyung ${ }^{f}$
}

\begin{abstract}
Abstrak
Tujuan penelitian ini adalah untuk meneliti aktivitas antikanker ekstrak etanol $70 \%$ daging buah Mahkota dewa (Phaleria macrocarpa (Scheff.) Boerl.) dengan menggunakan tumor payudara mencit C3H yang diinduksi dengan cara transplantasi. Tigapuluh dua mencit C3H dibagi secara acak menjadi 4 kelompok, yaitu 1 kelompok kontrol dan 3 kelompok yang mendapat ekstrak etanol daging buah Mahkota dewa masing-masing 20,40, dan 80 kali dosis manusia, diberikan secara oral melalui sonde lambung runtuk selama 30 hari, setelah transplantasi tumor. Berat mencit dan volume tumor diukur dua kali seminggu. Berat tumor ditimbang setelah hewan coba dimatikan (menggunakan eter), lalu difiksasi dengan formaldehid untuk pembuatan preparat histopatologis. Aktivitas proliferasi sel tumor dinilai dengan menghitung butir AgNOR setelah pewarnaan dengan perak nitrat koloidal. Apoptosis dinilai dengan pewarnaan Tunel, dan luas daerah nekrosis dinilai dengan pewarnaan hematoksilin eosin. Hasil penelitian ini memperlihatkan bahwa tidak ada perbedaan bermakna dalam volume tumor, berat tumor, nilai AgNOR, dan luas daerah nekrosis antara kelompok kontrol dan ketiga kelompok yang mendapat ekstrak etanol daging buah Mahkota dewa ( $p>0,05)$, tetapi indeks apoptosis meningkat secara bermakna pada kelompok D3 (ekstrak Mahkota dewa 80 kali dosis manusia) ( 2 <0,05). Dari penelitian ini disimpulkan bahwa ekstrak etanol daging buah Mahkota dewa 20,40,dan 80 kali dosis manusia, yang diberikan secara oral setelah transplantasi tumor untuk selama 30 hari, tidak menghambat pertumbuhan tumor payudara mencit C3H yang diinduksi dengan cara transplantasi, tetapi apoptosis meningkat pada kelompok yang mendapat ekstrak etanol daging buah Mahkota dewa 80 kali dosis manusia. (Med J Indones 2006; 15:217-22)
\end{abstract}

\begin{abstract}
The objective of this study is to investigate the anticancer activity of $70 \%$ ethanol extract of Mahkota dewa fruit pulp [Phaleria macrocarpa (Scheff.) Boerl.] using C3H mouse mammary tumor induced by transplantation. Thirty two C3H mice were devided into 4 groups i.e. control and 3 groups of mice treated with ethanol extract of Mahkota dewa fruit pulp with the dose of 20, 40, and 80 fold human dose respectively, given orally by gastric tube after tumor transplantation for 30 days. Body weight and tumor volume measured twice a week. Tumor weight was measured after the animal was sacrificed, then fixed in formaldehyde for making histopathological preparation. The proliferation activity of tumor cells were examined by counting the AgNOR deposits detected after colloidal AgNOR staining. Apoptosis was assessed by mean of Tunel staining, and the width of necrotic area was identified by hematoxyllin eosin staining of the histological specimen. The results of the study showed that there were no statistical differences in tumor volumes, tumor weights, AGNOR values, and the necrotic area among control and the three treated groups ( $p>0,05)$, but apoptosis index significantly increased in the D3 (Mahkota dewa extract of eighty fold human dose) group ( $p<0,05)$. It was concluded that ethanol extract of Mahkota dewa fruit pulp at the dose of 20,40, and 80 fold human dose given orally after tumor transplantation for 30 days, did not inhibit the C3H mouse mammary tumor growth induced by transplantation, but the increased apoptosis was found in the group receiving ethanol extract of Mahkota dewa fruit pulp at the dose of 80 fold human dose. (Med J Indones 2006; 15:217-22)
\end{abstract}

Keywords: Mahkota dewa, anticancer activity, proliferation, apoptosis

Until now, cancer is still being a health problem in the world. In Indonesia, according to Household Health

\footnotetext{
* Department of Pharmacology and Therapeutics, Faculty of

Medicine, University of Indonesia, Jakarta, Indonesia

${ }^{f}$ Department of Pathology Anatomy, Faculty of Medicine, University of Indonesia, Jakarta, Indonesia
}

Survey / Survei Kesehatan Rumah Tangga (SKRT) 2001 , the mortality rate caused by cancer is $4.9 \%$ in 1995 and it becomes $6.0 \%$ in 2001. Cancer is on the $5^{\text {th }}$ rank as the cause of mortality. ${ }^{1}$ Breast cancer is the $2^{\text {nd }}$ most common malignancy in women after the cervical cancer i.e. of $24.97 \%{ }^{2}$ 
Modern / synthetic anticancer drug available at present is usually expensive and it may cause severe adverse reaction, such as nausea, vomiting, diarrhea, alopecia, and bone marrow depression. Therefore, herbal medicine has become an alternative in cancer therapy. Herbal medicine is usually being used because it is less expensive, simply available, and it is believed as a safe and effective medicine.

One of herbal medicine that has been empirically used by a part of Indonesian community for cancer treatment is Mahkota dewa fruit pulp (Phaleria macrocarpa (Scheff.) Boerl). Some in vitro studies indicate that Mahkota dewa may inhibit HeLa and leukemia cell growth. $3,4,5$

For those reasons mentioned above, this study is aimed to investigate whether Mahkota dewa has in vivo anticancer activity in experimental animals.

The objective of this study is to investigate the anticancer activity of ethanol extract of Mahkota Dewa fruit pulp (Phaleria macrocarpa (Scheff.) Boerl), using in vivo experiment model of $\mathrm{C} 3 \mathrm{H}$ mouse mammary tumor induced by transplantation.

\section{Hypothesis}

Ethanol extract of Mahkota Dewa fruit pulp may inhibit the growth of $\mathrm{C} 3 \mathrm{H}$ mouse mammary tumor induced by transplant method.

\section{METHODS}

\section{Study design}

This study is a controlled in vivo experimental study using $\mathrm{C} 3 \mathrm{H}$ mice as the experimental animal.

\section{Study method}

Mice (Mus musculus L.) of $\mathrm{C} 3 \mathrm{H}$ strain were used as experimental animals. There were 32 mice, aged range 2-3 months, and 16-22 gram of weight, male and female, obtained from the Laboratory of Experimental Pathology, Department of Pathology Anatomy, Faculty of Medicine, University of Indonesia. Those mice were randomly devided into 4 groups, each group consists of 8 mice (based on Federer formula), i.e.:

1. Control Group: distilled water (aquadest) was given

2. D1 Group : $20 \mathrm{x}$ human dose $(240 \mathrm{mg} 70 \%$ ethanol extract of Mahkota dewa fruit pulp / $\mathrm{kgBW}$ ) was given
3. D2 group : $40 \mathrm{x}$ human dose $(480 \mathrm{mg} 70 \%$ ethanol extract of Mahkota dewa fruit pulp / $\mathrm{kgBW}$ ) was given

4. D3 group : $80 \mathrm{x}$ human dose $(960 \mathrm{mg} 70 \%$ ethanol extract of Mahkota dewa fruit pulp / $\mathrm{kgBW}$ ) was given

Either ethanol extract of Mahkota dewa fruit pulp or aquadest was given orally by gastric tube. The Mahkota dewa fruits were obtained from Bantul, Jogjakarta. The dose was determined based on human dose (body weight $50 \mathrm{~kg}$ ), i.e. $15 \mathrm{~g}$ of fresh Mahkota dewa fruit pulp or 1.5 dry powder.

Tumor transplantation was done on day 0 (1 day before treatment). The mammary tumor was obtained from donor mice. After tumor pulp was made, PBS solution was added in equal volume to the tumor pulp volume. By using a troche needle, $0.2 \mathrm{~mL}$ tumor pulp (minimal $10^{6}$ living cells) was injected subcutaneously into axillary region of recipient mice. ${ }^{6}$

One day after transplantation, $70 \%$ ethanol extract of Mahkota dewa fruit pulp dissolved in distilled water (aquadest) were given to D1, D2, and D3 groups, every morning for 30 days, while the control group got distilled water (aquadest).

Measurement of implanted tumor volume was carried out twice a week using a caliper (Tayima). Tumor length and width was measured, and tumor volume was calculated $\left(\right.$ volume $=$ length $\mathrm{x}$ width $\left.{ }^{2} \times 0.52\right){ }^{7}$ Mice weight was measured twice a week.

On the $31^{\text {st }}$ day, ether euthanasia was performed in all mice. Tumor tissue was removed, being weighted and fixed in $10 \%$ formalin buffer for histopathological examination using silver colloidal stain (AgNOR), Tunel stain and Hematoxyllin Eosin (HE) stain.

Silver colloidal stain (AgNOR). AgNOR stain was performed to detect cell proliferation and it was done according to Howat et al method. By using a light microscope and 100 time magnification, AgNOR granule counted in 50 cell nucleus of active tumor randomly in each gaze field. Counting was performed in 4 gaze fields ( 200 cell nucleus), and then AgNOR mean value was calculated for each slide. The counting was performed twice (in different day and hour). ${ }^{8}$

Tunel stain. Tunel stain was performed to detect apoptosis. Examination was done using a light microscope with 100 time magnification. Apoptosis 
cell was counted in 200 tumor cells of each gaze field, and it was performed in 5 gaze fields (1000 tumor cells). Observation was carried out twice (duplo) in different period of time. Apoptosis index was calculated using a formula of: ${ }^{9}$

$$
\mathrm{AI}=(\text { apoptosis cell } / \text { total tumor cells }) \times 100 \%
$$

Hematoxyllin esosin stain. Hematoxyllin eosin stain was performed to observe necrosis area. The extent of necrosis area was classified into 3 grades, i.e. ${ }^{10}$ :

0 : no necrosis was found in the examined slide

$1:$ necrosis less than $50 \%$ was found on the surface of examined tumor.

3 : necrosis more than $50 \%$ was found on the surface of examined tumor.

\section{Data analysis}

Significance test of mean value for tumor weight and volume, AgNOR granule and apoptosis index, which have been classified according to treatment group has been conducted. Data normality test has also been conducted by using Kolmogorov-Smirnov test. Homogenous data was analyzed by ANOVA and if there was any difference it was continued with Tukey analysis. Inhomogeneous data was analyzed by variant analysis using non-parametric test of Kruskal-Wallis. The data of necrosis area was ranked based on the necrosis area grades. Data analysis of non-parametric test of Kruskal-Wallis was employed. All of data was analyzed by using SPSS program $11^{\text {th }}$ version.

\section{RESULTS}

The results of the study both in the control group receiving aquadest and the three treatment groups which respectively received ethanol extract of Mahkota dewa fruit pulp with D1 dose (20 time human dose), D2 (40 time human dose) and D3 (80 time human dose) by oral administration for 30 days were as follows:

\section{Tumor volume}

In the $1^{\text {st }}$ week, tumor volume of control, D1, D2, and D3 group were $23.48 \pm 23.67 \mathrm{~mm}^{3} ; 45.73 \pm 40.15 \mathrm{~mm}^{3}$; $19.05 \pm 28.67 \mathrm{~mm}^{3}$ and $41.64 \pm 43.41 \mathrm{~mm}^{3}$ respectively. In the $2^{\text {nd }}$ week, the tumor volume were increased with the exception in D1 group the tumor volume was reduced to $34.75 \pm 26.71 \mathrm{~mm}^{3}$. In the $3^{\text {rd }}$ week, the tumor volume increased but were not as large as in the $2^{\text {nd }}$ week, and the D1 group had the smallest tumor volume $\left(38.49 \pm 42.38 \mathrm{~mm}^{3}\right)$. In the $4^{\text {th }}$ week, there were striking increase of tumor volume. In the last week, the tumor volume were keep increasing rapidly, the control group had $558.31 \pm 399.91 \mathrm{~mm}^{3}$; D1 group had $592.83 \pm 703.40 \mathrm{~mm}^{3}$; D2 group had $895.82 \pm 478.54 \mathrm{~mm}^{3}$; and D3 group had $1093.67 \pm 998.73$ $\mathrm{mm}^{3}$ (Figure 1). The statistical analysis indicated that there were no significant difference $(p>0,05)$ in tumor volume between the control group and the Mahkota dewa groups, except in the $3^{\text {rd }}$ week $(p<0.05)$.

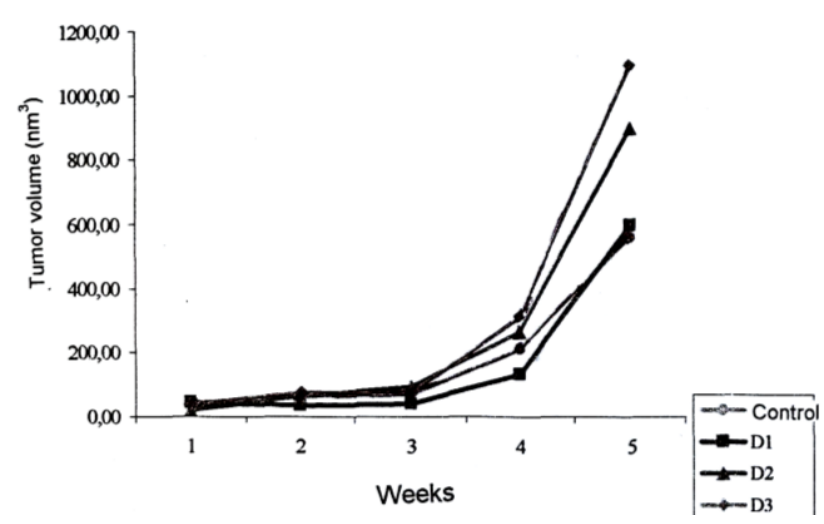

Figure 1. Tumor volume in the $1^{\text {st }}, 2^{\text {nd }}, 3^{\text {rd }}, 4^{\text {th }}$, and $5^{\text {th }}$ week in the control group and treatment groups of $\mathrm{C} 3 \mathrm{H}$ mice receiving $70 \%$ ethanol extract of Mahkota dewa fruit pulp $\left({ }^{*} p<0.05\right)$

\section{Tumor weight}

Tumor was removed and weighted (on day 31) after performing ether euthanasia in all mice. It was counted based on every $10 \mathrm{~g}$ mice, The control group had $0.32 \pm 0.16 \mathrm{~g}$ while D1 group had $0.36 \pm 0.41 \mathrm{~g}, \mathrm{D} 2$ had $0.47 \pm 0.29 \mathrm{~g}$, and D3 had 0.48 $\pm 0.44 \mathrm{~g}$. (Figure 2).

The statistical analysis indicated that there were no significant difference $(p>0.05)$ between the control group and the three treatment groups.

\section{AgNOR Value}

The AgNOR granule counting in 200 nucleus tumor cells demonstrated results as follows: the control group had $6.30 \pm 0.97$ while D1 group had $6.37 \pm 1.39$, D2 had 6.89 \pm 0.95 , and D3 had 7.25 \pm 1.19 (Figure 3). The characteristic of cell proliferation using AgNOR stain was shown in Figure 4. 


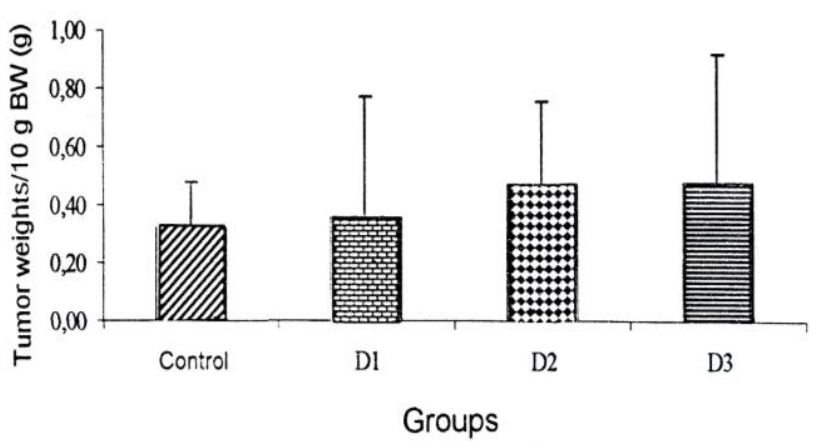

Figure 2. Mean value of tumor weight in $10 \mathrm{~g}$ body weight of $\mathrm{C} 3 \mathrm{H}$ mice of the control group and treatment groups receiving $70 \%$ ethanol extract of Mahkota dewa fruit pulp $(p>0.05)$

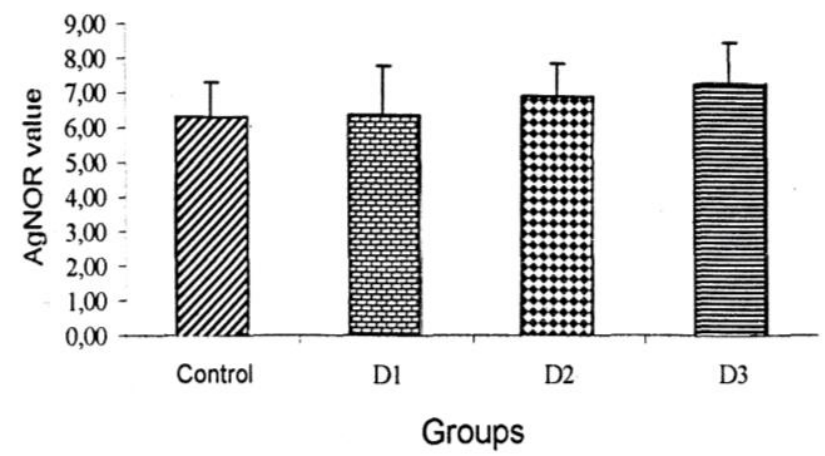

Figure 3. Average AgNOR value in the control group and treatment groups of $\mathrm{C} 3 \mathrm{H}$ mice receiving $70 \%$ ethanol extract of Mahkota dewa fruit pulp ( $p>0.05)$.

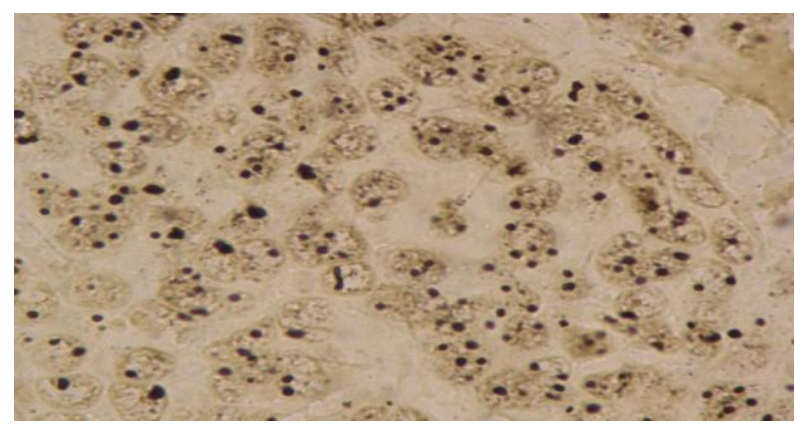

Figure 4. AgNOR stain examined by using light microscope with 100 time magnification.

Variant analysis was performed by one-way ANOVA test, which demonstrated no significant difference between the control group and the three treatment groups.
Based on the growth and proliferation parameters i.e. tumor weight, tumor volume and AgNOR value, it was indicated that there was no inhibitory effect of ethanol extract of Mahkota dewa fruit pulp on the growth of mammary tumor in $\mathrm{C} 3 \mathrm{H}$ mice, at the dose of 20,40, and 80 time human dose given orally after tumor transplantation for 30 days.

\section{Apoptosis Index}

Mean value of apoptosis index in the control group was $2.14 \pm 0.97 \%$, D1 group was $2.38 \pm 0.86$, D2 was $2.70 \pm 1.21 \%$; and D3 was $3.80 \pm 1.63 \%$ (Figure 5).

By using one way ANOVA test, it was found that apoptosis index was significant difference $(p<0.05)$ between the control group and the three treatment groups. Tukey test demonstrated significant difference only in D3 group ( $<0.05)$. It was indicated that oral administration of ethanol extract of Mahkota dewa fruit pulp with 80 time human dose in 30 consecutive days after tumor transplant, may induce apoptosis process in $\mathrm{C} 3 \mathrm{H}$ mouse mammary tumor .

If apoptosis index compared to the proliferation degree (AgNOR value), then the control group had $0.34 \pm 0.16$; D1 group had $0.38 \pm 0.12$; D2 group had $0.39 \pm 0.15$; and D3 group had $0.52 \pm 0.21$. One way ANOVA demonstrated no significant difference $(\mathrm{p}>$ 0.05 ) between the control group and the three treatment groups.

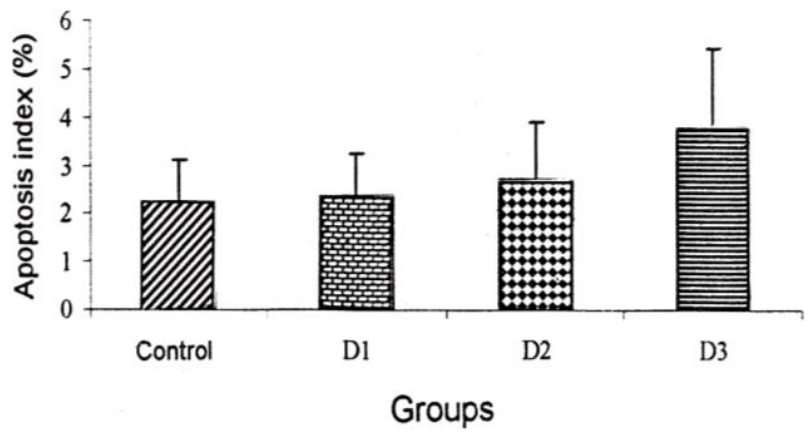

Figure 5. Mean value of apoptosis index in the control group and treatment groups of $\mathrm{C} 3 \mathrm{H}$ mice receiving $70 \%$ ethanol extract of Mahkota dewa fruit pulp $\left({ }^{*} p<0.05\right)$.

\section{Necrosis area}

Microscopic examination using hematoxylin eosin stain found necrosis in all of slides, and all were included in grade 1 , except 1 mouse in the control 
group, 3 mice in D1 group and 2 mice in D3 group were included in grade 3 (Figure 6).

Non-parametric test of Kruskal Wallis did not showed any significant difference $(p>0.05)$ between the control group and the treatment group. This data indicated that oral administration of ethanol extract of Mahkota dewa fruit pulp with 20, 40, 80 time human dose in 30 consecutive days after tumor transplant, did not induce cell death through necrosis process of tumor cells in $\mathrm{C} 3 \mathrm{H}$ mice mammary tumor.

Pearson correlation test indicated strong correlation between all parameters of tumor growth expressed in tumor weight, tumor volume in the $5^{\text {th }}$ week and tumor proliferation (AgNOR value). The larger tumor volume was, the heavier tumor weight and the greater AgNOR value was. Whereas, there was weak correlation between tumor growth and apoptosis index $(\mathrm{p}<0.05)$.
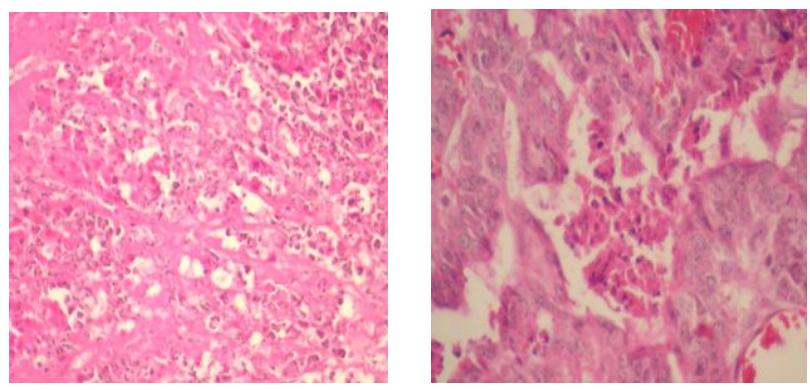

Figure 6. (a). Necrosis Area grade 3

(b). Necrosis Area grade 1, with HE stain, examined by using light microscope 40 time magnification.

\section{DISCUSSION}

Previous in vitro studies indicated that Mahkota dewa had a cytotoxic effect using shrimp larva death (BSLT) method and culture of leukemia cell L1210, P-388 and HeLa cell. ${ }^{4,5,11,12}$ Based on that fact, Mahkota dewa is also assumed to have in vivo anticancer activity in experimental animal. The $70 \%$ ethanol extract of Mahkota dewa fruit pulp was used in this study because at present, it is one of Mahkota dewa formulation available in the market.

From periodic volume measurement it was found that in the control group, almost all of tumor had emerged in the $2^{\text {nd }}$ week, while in the treatment group, several tumors emerged in the $4^{\text {th }}$ or even $5^{\text {th }}$ week. Statistical analysis demonstrated significant difference of tumor volume between D1 group and the control group in the $3^{\text {rd }}$ week, but on the following week the tumor volume increased rapidly.

In this study, ethanol extract of Mahkota dewa fruit pulp did not inhibit tumor growth and proliferation because there was no significant difference in tumor volumes, tumor weights and AgNOR values between the treatment groups and the control group ( $p>0.05$ ). But in Mahkota dewa with 80 time human dose induced cell death through apoptosis. Increased apoptosis in this group apparently could not keep increased cell proliferation equally. Increased apoptosis in D3 group was similar to in vitro study conducted by Subroto A and Mimura A (2006) by using various culture of monkey leukemia P388 cell, monkey P16/BL6 cell, monkey colon 26/LS cell, monkey LLC cell, human HeLa cell and human lung A549 cell. ${ }^{13}$ Mahkota dewa is assumed has a cytotoxic content, namely lignant (polyphenol) compound because its structure similar to syringaresinol of Wikstroemia elliptica and Mistletoe herb, which also have a cytotoxic effect. Mistletoe has cytotoxic effect through increasing the activity of NK (Natural Killer) cell and PMN leukocytes.

Disparities between this study result and in vitro study result mentioned above may be caused by : 1 . the active ingredients which has anticancer activity in ethanol extract of Mahkota dewa fruit pulp may be present in small amount, therefore it may not inhibit tumor growth. (2) the utilized extract is a coarse extract containing various compounds such as phenol, flavonoid, tannin and saponin, ${ }^{3,14}$ which these compounds may affect each other and may have antagonize effect. ${ }^{15}$ (3) the extraction solvent is inappropriate so it may not attract the active ingredient which has anticancer effect. (4) Thirty days Mahkota dewa treatment is too brief therefore it may not inhibit the growth of $\mathrm{C} 3 \mathrm{H}$ mice mammary tumor (5) $\mathrm{C} 3 \mathrm{H}$ mice mammary tumor is not sensitive against ethanol extract of Mahkota dewa fruit pulp.

\section{CONCLUSION AND SUGGESTIONS}

\section{Conclusion}

Oral administration of ethanol extract of Mahkota dewa fruit pulp at the dose of 20,40, 80 time human dose for 30 days after tumor transplant, does not inhibit the growth of $\mathrm{C} 3 \mathrm{H}$ mice mammary $(\mathrm{p}>0.05)$, 
but there is a significant increased of apoptosis $(p<0.05)$ at the dose of 80 time human dose.

\section{Suggestions}

Further study should be conducted to investigate anticancer activity of Mahkota dewa fruit pulp by using:

1. Another solvent or extract, such as ethyl acetate and hexane

2. Other tumor type such as leukemia and cervical cancer cells

3. Administration of Mahkota dewa fruit pulp extract in mice that already has certain size of tumor after undergoes tumor transplantation.

\section{REFERENCES}

1. Djaya S, Soemantri S, Irianto J. Perjalanan transisi epidemiologi di Indonesia dan implikasi penanganannya, study mortalitas-survai kesehatan rumah tangga (19862001). Bul Penel Kes 2003; 31(1) : 119-31

2. Kanker di Indonesia tahun 1999 Data Histopatologik. Dep. Patologi Klinik, FKUI, Dirjen Yan. Medik Depkes RI, Badan Registrasi Kanker,YKI.

3. Kardono LBS. Kajian kandungan kimia Mahkota dewa [Phaleria macrocarpa (Scheff.) Boerl.]. Seminar sehari Mahkota dewa. 2003

4. Hakim R W, Nawawi A, Adyana IK, Ahmad SA, Makmur L, Hakim E, Sjah YM, Kitajima M. Glukosida benzofenon dari buah merah Mahkota dewa [Phaleria macrocarpa (Scheff.) Boerl.] serta uji aktivitas terhadap DPPH dan sel murin leukemia P-388. Bull Soc Nat Prod Chem (Indonesia). 2004; 4 : 67-70.

5. Lisdawati V. Brine shrimp lethality test (BSLT),Bioasai antikanker in vitro dengan sel leukemia L1210, dan isolasi serta penentuan struktur molekul senyawa kimia dari buah
Mahkota [Phaleria macrocarpa (Scheff.) Boerl.] (tesis). FMIPA UI. 2002.

6. Gupta V, Carey JL, Kawakubo H, Muzikansky A, Green JE, Donahue PK. Mullerian inhibiting substance suppress tumor growth in the C3(1)T antigen transgenic mouse mammary carcinoma model. Proc Natl Acad Sci USA. 2005; 102(9): 3219-24.

7. Cox C. Inhibition of the growth of squamous cell carcinoma by tetrathiomolybdate-induced copper suppression in a murine model. Circulation research. 2004; 95: 415

8. Behrem-senija E, Zlatko T, Mladen P, Renata DB, Milivoj D, Nives J. Prognostic significance of DNA ploidy pattern and nucleolar organizer regions (AgNOR) in colorectal carcinoma.Croat Med J. 2000; 41:154-8

9. Lu XG, Zhan LB, Feng BA, Qu MY, Yu LH, Xie JH. Inhibition of growth and metastasis of human gastric cancer implanted in nude mice by d-limonene. World $\mathrm{J}$. Gastroenterol. 2004; 10(14) : 2140-4

10. Gumay S, Permasalahan dalam menegakkan diagnosis sarkoma jaringan lunak dalam. kursus lanjut patologi jaringan lunak dan penyakit tropik, Bag. Patologi Anatomik FKUI 1996.

11. Prasetya INB, Djunarko I, Donatus IA. Efek hepatoprotektif infus daging buah makuto dewo [Phaleria macrocarpa (Scheff.) Boerl.] pada mencit jantan terinduksi parasetamol. Risalah penelitian ilmiah nasional, Fak. Farmasi Univ.Sanata Dharma, Yogyakarta. 2003; 38-45.

12. Purwantini I, Setyowati EP, Hertiani T. Uji toksisitas ekstrak etanol : buah, biji, daun, makuta dewa [Phaleria macrocarpa (Scheff.) Boerl.] terhadap Artemia salina Leach dan profil KLT ekstrak aktif. Maj.Farmasi Indonesia. 2002;13(2): 101-6.

13. Subroto A, Mimura A. Elucidation of biological activity of components in Mahkota dewa .(inpress)

14. Widowati L. Kajian hasil penelitian Mahkota dewa [Phaleria macrocarpa (Scheff.) Boerl.], Puslitbang Farmasi dan OT. 2004.

15. Mills S, Bone K. Principles of herbal pharmacology in principles and practice of phytotherapy, modern herbal medicine. Churchill Livingstone. Edinburg. 2000; 22-70. 